\title{
ONTOLOGI HIBUA LAMO DALAM PERSPEKTIF JÜRGEN HABERMAS
}

\author{
Oleh: Ricardo F. Nanuru ${ }^{1}$
}

\begin{abstract}
Hibua Lamo is a cultural system that binds communities in North Halmahera. It is a form of conflict resolution among the communities by harmonizing interests between conflicting groups as well as binding the groups into a new relationship bond. It was tested by riots of Moluccas, including North Halmahera. This study shows that there is a difference context of emergence between Habermas's thought and local knowledge of Hibua Lamo. However, based on the Habermas's perspective of communication ratio, Hibua Lamo at least get the spirit to a new birth. Based on the new understanding, Hibua Lamo now exists to rely on communicative ratio which is able to withstand annexation of market system and the state, and also to tie the communities in North Halmahera through peace consensus.
\end{abstract}

Keywords: Hibua Lamo, Jürgen Habermas, local knowledge, communicative ratio.

\section{A. Pendahuluan}

Halmahera Utara merupakan salah satu kabupaten hasil pemekaran yang terbentuk pada tanggal 31 Mei 2003. Luasnya $24.983,32 \mathrm{~km}^{2}$ dengan 22 kecamatan yang terbagi atas 260 desa. Ibukotanya terletak di Tobelo yang berjarak 138 mil laut dari Ternate, ibukota Provinsi Maluku Utara. Posisi kabupaten ini berada tepat di bibir Samudera Pasifik. Bagian Utara berbatasan dengan Samudera Pasifik, bagian Timur berbatasan dengan Kabupaten Halmahera Timur dan Laut Halmahera, sedangkan bagian Selatan dan Barat berbatasan dengan Kabupaten Halmahera Barat (http://www.halutkab.go.id).

Orang-orang Halmahera Utara, yang terdiri atas kelompok etnis Tobelo, Tobaru, Galela, dan Loloda, selalu menanggapi bahwa kenyataan kehidupan ini tidak pernah sepi dari kesadaran religiusitas yang mereka anut. Seluruh bidang kehidupan, baik bidang pertanian, perburuan, nelayan, kelahiran anak, hubungan

\footnotetext{
${ }^{1}$ Staf Pengajar pada Fakultas Teologi Universitas Halmahera.
} 
dengan sesama manusia, maupun sikap manusia terhadap alam sekitar, selalu dihayati dalam kaitannya dengan kesadaran religiusitas mereka. Kesadaran religiusitas yang hidup di kalangan masyarakat Halmahera ini memiliki kekuatan yang mampu membentuk kepekaan seseorang terhadap kehendak Yang Ilahi bagi hidupnya, dan sekaligus membentuk sikap dan perilaku seseorang dalam menyikapi sesamanya dan alam sekitarnya (Mojau, 2001:1).

Masyarakat Halmahera, selain memiliki kesadaran religiusitas, juga memiliki kesadaran sejarah (historical consciousness) yang menjadi daya dorong yang sangat kuat dalam usaha memahami serta menafsirkan fenomena sosial sampai ke dasar ontologis dari mengadanya manusia dan/atau masyarakat. Ini merupakan suatu proses memahami (verstehen) dan sekaligus menjelaskan (erklaren), dengan sedapat-dapatnya menyajikan bukan saja pemahaman seseorang atau sekelompok orang tetapi juga "hal mengada" mereka yang mencakup perkataan, cerita, ungkapan-ungkapan tradisional, karya dan cipta manusia, termasuk juga mitos. Memahami masyarakat dalam kerangka sosio-historis merupakan suatu usaha yang perlu menyertakan berbagai perangkat dan pranata sosial masyarakat. Di samping itu, pergeseran sistem dan struktur sosial di dalam perjalanan sejarah serta reaksi dan prokreasi masyarakat juga merupakan bagian yang tak bisa disepelekan. Salah satu aspek yang dapat dikatakan menonjol dalam rangka memahami masyarakat adalah sistem kepercayaan atau corak beragama masyarakat tersebut, seperti yang di atas dibahasakan sebagai kesadaran religiusitas. Hal ini bertindihan tepat dengan world view atau kosmologi yang lahir dari suatu kebudayaan dalam habitual-nya (Maspaitella, 2008: http://kutikata.blogspot.com/2008/01/solohuakasale-patai.html).

Aspek tersebut menunjuk pada apa yang kemudian disebut sebagai identitas suatu masyarakat yang berpengaruh pada mengadanya masyarakat pada masa kini, sama seperti yang dikemukakan Kuntowijoyo (2003:59-90) ketika mengulas "sejarah desa" dan "sejarah kota", sebagai bagian dari kesadaran sejarah untuk menjelaskan postur perkembangan masyarakat itu sendiri. Oleh karena itu pendekatan sosio historis mencakup pula pandangan dunia masyarakat setempat (Vanisna, 1969:133-135).

Suatu corak pandangan dunia yang menekankan adanya wilayah batas antara dimensi sakral dan profan telah dijelaskan oleh beberapa tokoh, seperti Durkheim dan Eliade. Keduanya membagi dan membedakannya menjadi semacam lingkungan yang kemudian 
dilegitimasikan melalui ritus dan juga mitos, seperti dijelaskan Dhavamony. Secara antropologis, pandangan dunia tampak pada bagaimana masyarakat menetapkan suatu lingkungan pusat (center of the world) sebagai titik penghubung antara bumi - langit - dan bawah bumi. Hal ini adalah semacam corak yang melaluinya kita menjumpai bahwa dunia terkadang disimbolisasikan dengan tugu batu, bangunan rumah, gunung, pohon, tanah, sebagai suatu usaha mematerialisasikan tingkatan dunia untuk kepentingan religiusitas masyarakat. Konstruksi semacam ini mempengaruhi perilaku religius masyarakat, misalnya menjadikan sebatang pohon sebagai "pohon suci/ keramat", atau "gunung suci", "mata air keramat", sebagai suatu pusat bagi ritus dan agama (Maspaitela, 2008: http://kutikata.blogspot.com/2008/01/solohua-kasale-patai.html).

Adanya perhatian yang tertuju pada pandangan dunia seperti tersebut di atas, kemudian membentangkan dimensi waktu, ruang,dan proses sejarah sebagai tiga konsep keilmuan yang padu padan dalam historitas (Wachterhauser, 1986: 7). Bangunan atau rumah sebagai hasil karya budaya material masyarakat dalam konsepsi tersebut menempati sebagian dari ruang budaya sebagai pencapaian jati diri masyarakat. Rumah juga mengandung pesanpesan (message) sebagai bentuk formatif dari adanya korelasi imanen masyarakat dengan lingkungan. Rumah merupakan bentuk aktual dari budaya dan benar-benar berdasar pada dan di dalam sejarah. Berartinya makna rumah di dalam ruang budaya ini pula yang kemudian menjadi ide dasar bagi kajian mengenai Hibua Lamo ini, yakni sebuah rumah bersama yang memiliki arti yang penting bagi masyarakat Halmahera Utara.

Hibua Lamo merupakan rumah adat sekaligus menjadi "payung" budaya masyarakat yang ada di Halmahera Utara. Bahkan pada tataran tertentu, Hibua Lamo diidentikkan dengan masyarakat Halmahera Utara itu sendiri. Berdasarkan hal itu maka tulisan ini dibuat, yaitu untuk lebih memperkenalkan budaya Hibua Lamo secara umum bagi kalangan masyarakat yang lebih luas. Hal lain yang mendasari kajian ini adalah kegelisahan penulis yang melihat kondisi aktual budaya lokal yang semakin terpinggirkan dengan tidak berfungsinya lembaga-lembaga adat, melemahnya pranatapranata sosial budaya di masyarakat, bahasa lokal yang hampir punah, dan sebagainya, yang juga melanda bumi Hibua Lamo, Halmahera Utara.

Kondisi-kondisi riil di atas, menurut penulis, terjadi karena beberapa hal, antara lain kuatnya dominasi kekuasaan yang 
dilakukan penguasa melalui berbagai kebijakan publik, nilai-nilai budaya global yang ditawarkan melalui media komunikasi dan informasi modern yang telah mempengaruhi semua aspek kehidupan masyarakat. Agama juga tidak dapat disangkal turut memberikan kontribusi dalam melemahkan peran budaya lokal. Sosialisasi budaya lokal sangat jarang dilakukan serta tidak adanya kebijakan tentang kebudayaan yang bertujuan untuk mengembangkan identitas lokal sebagai bagian dari identitas nasional.

Selain itu upaya pengkajian terhadap nilai-nilai budaya rumah adat masyarakat di Halmahera Utara atau yang lebih dikenal sebagai Hibua Lamo belum banyak dilakukan, atau dapat dikatakan belum ada yang dipublikasi secara ilmiah. Hal ini terlihat dengan tidak ditemukannya literatur yang membahas Hibua Lamo secara khusus. Hal inilah yang memotivasi penulis untuk melakukan penelitian ini. Walaupun demikian sudah ada beberapa tulisan terkait topik di atas yang dapat penulis angkat sebagai referensi yang dapat dipakai sebagai perintis tulisan ini. Tulisan ini merupakan rintisan yang dapat bermanfaat bagi pengkajianpengkajian selanjutnya tentang Hibua Lamo di Halmahera Utara. Harapan terbesar dari tulisan ini adalah budaya lokal Hibua Lamo dapat terus bertahan dan dikembangkan oleh masyarakat Halmahera Utara sebagai pemiliknya.

\section{B. Hibua Lamo: Selayang Pandang}

Pada tanggal 19 Januari 1999, pecah kerusuhan massal di Ambon, Maluku yang berimbas ke Maluku Utara termasuk Halmahera Utara. Kerusuhan massal ini merupakan tragedi paling berdarah di Indonesia karena menelan ribuan korban jiwa. Maluku dan Maluku Utara (di dalamnya ada Halmahera Utara) mengalami saat-saat paling kelam dalam sejarahnya. Hubungan-hubungan yang dibangun dalam kerangka integrasi sosial selama puluhan tahun, bahkan ratusan tahun, hancur hanya dalam hitungan hari. Namun demikian, ada satu hubungan kekerabatan dalam budaya masyarakat Halmahera Utara yang mampu bertahan dari konflik tersebut dan masih eksis sampai saat ini, yaitu Hibua Lamo.

Eksistensi Hibua Lamo, yang hingga sekarang masih bisa dilihat, tidak dapat dilepaskan dari pandangan dunia yang dimiliki oleh Masyarakat Halmahera Utara. Masyarakat Halmahera Utara memiliki pandangan dunia (world view) tersendiri mengenai rumah adat mereka. Pandangan ini sangat erat berhubungan dengan sejarah Hibua Lamo itu sendiri. Eksistensi Hibua Lamo di Halmahera Utara 
dimulai ketika nenek moyang masyarakat Halmahera Utara, yang terdiri dari sembilan Soa (Soa: semacam klan atau kumpulan kekerabatan keluarga), bergerak meninggalkan daerah tempat tinggalnya di Talaga Lina (Talaga: danau) menuju ke tempat yang lebih menjanjikan dalam hal peningkatan taraf kehidupan (sumber dari cerita ini diambil dari tulisan Clion K. Labada, 2007, Asal-usul dan Eksistensi Hibualamo :http://www.halmaherautara.com)

Lima dari sembilan Soa yang dimaksud pergi menuju wilayah Kao dan empat lainnya menuju wilayah Tobelo. Keempat Soa itu adalah Soa Lina, Soa Huboto, Soa Momulati, dan Soa Gura.Kelompok yang berasal dari empat Soa itu menuju arah utara (O Koremie Uku, artinya menuju arah angin utara) yang sekarang dikenal sebagai wilayah Tobelo. Halmahera Utara saat itu berada di bawah pemerintahan Sultan Ternate. Singkat cerita, mereka tiba di suatu tempat yang kemudian mengalami bencana kebakaran. Sultan Ternate pun mengunjungi mereka, dan oleh Sultan Ternate, wilayah itu dinamai 'Gamhoku' (Gam: negeri, Hoku: terbakar). Setelah itu mereka melanjutkan perjalanan dan tiba di tempat yang diberi nama 'Tobeloho', yang artinya bertancap, dalam arti luas kata tersebut berarti 'saya tidak akan kemana-mana lagi'.

Tekad mereka untuk kehidupan yang lebih baik tentunya memerlukan kesabaran yang dibarengi rasa kekeluargaan yang tinggi sehingga Sultan Ternate mengajak mereka untuk bersamasama membangun sebuah tempat bernaung yang mampu menampung banyak orang. Sesuai kesepakatan dari keempat Soa, dibangunlah sebuah rumah besar yang dalam bahasa daerah biasa dikenal dengan nama Hibua Lamo. Bentuk bangunan Hibua Lamo, pada saat itu relatif bundar dan sederhana karena sangat dipengaruhi oleh peristiwa melilitkan gadoro atau iwi atau uri di pergelangan tangan masing-masing.

Seiring dengan perubahan-perubahan yang terjadi dalam masyarakat, eksistensi Hibua Lamo pun mulai bergeser. Apalagi setelah terjadi konflik bernuansa SARA yang melanda Maluku dan merambat ke Maluku Utara, termasuk Halmahera Utara, membuat pandangan terhadap Hibua Lamo juga bergeser dari arti sebelumnya. Hibua Lamo, dalam hal ini terkesan ditafsirkan secara baru. Selain itu, arsitekturnya pun tidak sama lagi dengan bentuk aslinya (Hibua Lamo versi modern). Hibua Lamo masa kini difungsikan sebagai tempat dilaksanakannya upacara-upacara adat dan sebagai tempat pertemuan pemimpin dan rakyat. Rumah adat kebanggaan masyarakat Halmahera ini memang sudah mengalami 
modifikasi dari bentuk aslinya. Meski demikian, ia tetap merupakan simbol rekonsiliasi dan persatuan bagi masyarakat Halmahera Utara.

\section{Hibua Lamo Sebagai Nilai Kekeluargaan Yang Mempersatukan}

Kebudayaan daerah atau kebudayaan lokal merupakan bagian dari kebudayaan nasional dan memiliki posisi yang sama antara daerah yang satu dengan yang lain di Indonesia. UndangUndang Dasar 1945 menyatakan bahwa kebudayaan nasional merupakan puncak kebudayaan daerah. Oleh karena itu, kebudayaan daerah maupun kebudayaan nasional harus memiliki daya perekat bagi anggota masyarakat dan bangsa, memiliki kekuatan integrasi, mendorong kemajuan, dan mengembangkan kesetaraan antara anggota masyarakat dan antarbangsa (Ajawaila, 2009: 33).

Sejalan dengan pandangan di atas, Hibua Lamo sebagai budaya daerah turut menyumbang bagi pengembangan kehidupan bermasyarakat di Halmahera Utara dan sekitarnya. Secara fisik, Hibua Lamo dibangun sebagai tempat pertemuan orang Tobelo masa lalu dan menjadi tempat tinggal bagi mereka yang mengikuti pertemuan-pertemuan adat tetapi kampungnya terletak jauh dari tempat Hibua Lamo berada. Seiring dengan perkembangan pemahaman masyarakat, maka istilah Hibua Lamo juga mengalami perkembangan dan dipahami bukan saja sebagai bangunan fisik tetapi dipahami sebagai masyarakat itu sendiri (Mesdila, 2005: 53).

Sebelum ada sistem pemerintahan yang modern seperti sekarang ini, masyarakat Halmahera Utara telah memiliki sistem adat yang mengatur hampir keseluruhan kehidupan masyarakat. Semua masalah dan hal-hal yang dipikir penting akan dibicarakan di dalam Hibua Lamo dan masyarakat taat terhadap putusan yang telah dibuat. Hibua Lamo penting bagi masyarakat Halmahera Utara karena menyatukan masyarakat dalam satu kebudayaan, dan berfungsi sebagai pelengkap komunitas serta berupaya untuk melestarikan adat yang relevan dengan kondisi zaman. Selain itu, Hibua Lamo penting karena menampung komunitas yang berbeda agama dalam satu lembaga yang diikat oleh ikatan kekeluargaan. Secara sosiologis, kesatuan sosial yang mengakar tersebut telah menjadi semacam kontrak sosial yang mengikat masyarakat Halmahera Utara. Sebagai suatu kontrak sosial, konsensus bersama menjadi dasar berpijak untuk hidup bersama sebagai masyarakat 
Halmahera Utara (Mesdila, 2005: 54-55).

Masyarakat Hibua Lamo tidak mengenal adanya hierarki atau keturunan raja-raja, sultan, dan sebagainya yang memiliki posisi lebih tinggi. Dalam masyarakat adat Hibua Lamo kedudukan masyarakatnya sama dan tidak memiliki perbedaan. Hal ini berbeda dengan suku-suku lainnya di Maluku Utara. Di Tidore, Bacan, dan Jailolo pemimpinnya adalah seorang sultan dengan pemerintahan yang didasarkan pada sistem warisan sehingga keturunan sultan yang mutlak memerintah wilayah-wilayah dimaksud secara turunmenurun. Dalam sistem pemerintahan masyarakat Hibua Lamo gelar Jiko Makowano ('Raja Teluk' disebut juga dengan istilah Jiko Makolano, dalam pembahasan ini akan dipakai bergantian disesuaikan dengan sumber kutipan) tidak dianugerahkan berdasarkan warisan tetapi didasarkan pada pemilihan. Adapun sistem pemilihan Jiko Makowano dikenal dengan istilah $O$ Higaro (saling mengajak dan saling menguji calon pemimpin). Proses pelaksanaannya dimulai dengan berkumpulnya tokoh-tokoh adat dari masing-masing hoana di Hibua Lamo dan seterusnya menentukan calon. Kemudian calon diuji kemampuannya baik dalam pengetahuan maupun kehebatannya sebagai seorang ksatria. Pemimpin yang terpilih adalah orang yang benar-benar tahan uji dan merupakan yang terbaik serta dapat dijadikan teladan bagi masyarakat secara umum (Kuat, 2009: 53). Dengan demikian, higaro merupakan proses bersama-sama untuk mencapai tujuan yang dikehendaki bersama, dan produknya memiliki kekuatan hukum yang seharusnya dipatuhi oleh komunitas yang ikut dalam proses higaro (Namotemo, 2009: 11).

Masyarakat adat Hibua Lamo mengenal semacam lembaga legislatif yang dinamakan $O$ Hoana Mahaeke. Lembaga ini semacam badan musyawarah yang berfungsi mengatur tata nilai kehidupan keempat hoana dalam budaya Hibua Lamo. Di pihak lain, $O$ Jiko Makowano berfungsi sebagai badan eksekutif yang bergerak dalam pelaksanaan pemerintahan. Sedangkan badan yang mengurus persoalan hukum atau peradilan adat, baik pelestarian nilai-nilai, pendampingan hak-hak masyarakat adat, maupun pengembangan dan pemberdayaan komunitas masyarakat adat dikenal dengan nama $O$ Adati Majojo (Mesdila, 2005: 54).

Jiko Makolano merupakan figur pemimpin yang selalu berhigaro untuk mewujudkan harapan dari masyarakat yang dipimpinnya. Dengan demikian, dalam kepemimpinan masyarakat adat Hibua Lamo seorang Jiko Makolano harus menjadi pola 
anutan, sumber inspirasi, pengayom dan mempunyai kharisma yang dihargai dan dihormati oleh masyarakat yang dipimpinnya, sehingga bisa menjadi harapan masyarakat (jiko mangongano). Dalam pelaksanaan tugas dan fungsi Jiko Makolano pada wilayah tertentu, dibantu oleh hoana mangongano (setingkat camat) dan gogere mahaeke (setingkat kepala desa). Mengenai urusan keamanan dalam wilayah adat Hibua Lamo, terdapat perangkat kepemimpinan Jiko Makolano yang dinamakan Hoana Magogoana yang dipimpin oleh seorang kapita (semacam kepala pasukan) (Namotemo, 2009: 11-12).

Ada lima anasir utama dalam budaya Hibua Lamo yang saling terkait dan tak dapat dipisahkan satu dengan yang lainya. Lima anasir adat tersebut adalah $O$ dora, $O$ hayangi, $O$ baliara, $O$ adili dan $O$ diai yang diuraikan Kuat (2009: 54-57) sebagai berikut:

1) $O$ dora, dapat diartikan dengan 'kasih', yakni kasih terhadap sesama manusia (antar individu) maupun antara individu dengan masyarakat. $O$ dora memiliki makna mendalam sebagai dasar (foundation) hubungan saling mengasihi antar sesama, juga diri sendiri. Inilah unsur yang mengikat mereka ke dalam suatu masyarakat yang rukun, damai dan aman. Wujud dari $O$ dora dapat dilihat pada kebiasaan membagi rejeki (hasil tangkapan di laut maupun buruan).

2) $O$ hayangi, maknanya sama dengan kata 'sayang' yang artinya masih dekat pula dengan $O$ dora, akan tetapi $O$ hayangi lebih dekat maknanya pada tolong-menolong serta saling menjaga perasaan, dan tidak saling menyakiti apalagi saling membunuh. Wujud dari $O$ hayangi dapat dilihat pada saat adanya orang sakit maupun meninggal dunia, yakni masyarakat yang bahumembahu untuk meringankan penderitaan ataupun dukacita dari keluarga yang ditimpa kemalangan. Selain itu, suasana tolongmenolong ataupun gotong royong yang oleh masyarakat Hibua Lamo di sebut Hirono, dapat dilihat pada saat membuka lahan baru untuk perkebunan, membangun rumah, termasuk membangun rumah ibadah antar komunitas yang berbeda agama. $O$ hayangi pada prinsipnya adalah bentuk empati di antara sesama warga untuk saling meringankan beban.

3) $O$ baliara, dapat diartikan sebagai 'pelihara' yang mengandung pengertian saling peduli, saling menopang atau menunjang, saling melayani dalam rangka menciptakan menciptakan kehidupan bersama yang makmur, aman dan damai. Hal-hal negatif yang mengganggu kehidupan bersama harus dihindari sebagai 
wujud tanggung jawab bersama tanpa rasa keterpaksaan atau dipaksakan untuk memelihara atau pun melanggengkan suasana yang baik (kondusif).

4) $O$ adili, artinya 'keadilan' yang di dalamnya mengandung makna kesetaraan derajat, harkat dan martabat, kesetaraan hak dan kewajiban di depan aturan-aturan normatif yang diakui dan diterima sebagai hukum adat yang sangat dijunjung. Semua aktivitas dalam kehidupan bersama dilaksanakan secara bijaksana dan penuh kehati-hatian sehingga berbagai bentuk kesetaraan sebagaimana disebutkan di atas tidak terganggu atau pun dilecehkan. Kecurangan, penipuan dan perbuatan lainnya yang melanggar norma adat sebagai wujud ketidakadilan sangat dikecam. Setiap anggota, oleh karenanya, wajib memelihara kesetaraan dan keseimbangan untuk menciptakan suasana keadilan dalam masyarakat.

5) $O$ diai, dapat disamakan dengan kebenaran yang erat kaitannya dengan $O$ adili (keadilan). Norma yang diterima, disepakati dan dihargai sebagai "yang benar" merupakan kriteria yang menentukan "YA bagi yang benar, dan TIDAK bagi yang salah". Oleh karena itu, masyarakat setempat sangat tegas untuk menyatakan sikap, baik untuk hal-hal yang dianggap salah maupun bagi yang dianggap benar. Implementasi $O$ diai dalam kehidupan bersama pada masyarakat Hibua Lamo tercermin lewat pengambilan keputusan terhadap perkara-perkara, yakni dalam sikap para ketua adat yang selalu tegas tanpa pandang bulu dalam menentukan keputusan. Mereka, para ketua adat, harus dengan tegas memberi sanksi walaupun yang menjadi "terdakwa" adalah salah satu anggota keluarga mereka sendiri. Hal ini dilakukan untuk menjaga agar kebenaran yang diikuti keadilan benar-benar merata dalam tatanan kehidupan Hibua Lamo.

Masyarakat Hibua Lamo juga terkenal sebagai masyarakat yang demokratis. Berdasarkan pengalaman konflik sosial yang terjadi yang terjadi tahun 1999 di Maluku, termasuk Halmahera Utara, dan proses penyelesaiannya dengan rekonsiliasi yang tetap bertahan sampai saat ini, terbukti bahwa masyarakat Hibua Lamo tetap berpegang pada nilai-nilai adat yang demokratis yang tidak lenyap ditelan perubahan global. Memang tidak dapat dipungkiri bahwa saat ini fungsi Hibua Lamo tidak lagi persis seperti dulu karena telah tergantikan oleh balai desa, kantor camat, kantor polisi, kantor pengadilan, dan kantor bupati yang sering menjadi tempat 
pertemuan serta penyelesaian masalah. Sedangkan Hibua Lamo hanya digunakan sebagai tempat pelaksanaan ritual keagamaan atau pun pertemuan-pertemuan akbar, baik oleh pemerintah maupun masyarakat, misalnya ketika ada kunjungan tamu dari luar daerah atau pengangkatan sesepuh adat. Walaupun pertemuan khusus untuk tokoh-tokoh adat dan masyarakat yang melibatkan semua komponen Hibua Lamo telah jarang dilaksanakan, namun tidak berarti pemahaman serta implementasi nilai-nilai adat demokratis tidak terdapat lagi atau hilang dari kehidupan masyarakat. Justru sebaliknya, nilai demokratis dari Hibua Lamo tetap menjiwai setiap agenda kehidupan masyarakat (Kuat, 2009: 59).

Implementasi nilai demokratis dalam adat Hibua Lamo yang merupakan wujud dari $O$ adili sampai saat ini masih terlihat dalam proses penyelesaian masalah. Ketika terjadi masalah keluarga dalam masyarakat adat Hibua Lamo para ketua adat atau pemangku adat di tiap-tiap desa masih memiliki peran penting dalam penyelesaian masalah dimaksud dan keputusan yang mereka ambil masih diakui oleh masyarakat sehingga peran aparat keamanan ataupun kepolisian tidak terlalu dibutuhkan untuk menyelesaikan persoalan dimaksud. Nilai demokratis lainnya dapat dilihat dalam sejarah pemilihan Jiko Makowano yang pada prinsipnya tidak memandang perbedaan dalam beberapa hoana, yakni ketika semua keputusan yang diambil untuk menetapkan pemimpin selalu didasarkan pada kesepakatan bersama sehingga masyarakat dapat menerima keputusan dimaksud secara umum (Kuat, 2009: 59-60).

Selain demokratis, masyarakat adat Hibua Lamo dikenal juga sangat religius. Setiap tata kelakuan masyarakat adat Hibua Lamo tidak terlepas dari mitos maupun tata tertib alam. Mereka menghayati akan adanya kehadiran "Yang Suci" melalui fenomena alam. Eksistensi dari segala sesuatu yang ada dalam kosmos diyakini tidak terjadi dengan sendirinya tetapi ada yang "mengadakan" karena itu segala sesuatu ada "yang empunya". Dari pemahaman itulah maka apa yang disebut Yang Suci dalam pandangan masyarakat Hibua Lamo disebut sebagai Gikiri, yaitu suatu pribadi absolut yang senantiasa ada dalam alam. Selain itu Gurumini (roh leluhur) pun diakui sebagai pribadi yang dijadikan panutan dalam tata kelakuan sehingga harmoni dalam kehidupan antara sesama maupun dengan yang absolut dapat terjaga. Ciri khas religiusitas masyarakat Hibua Lamo yang sangat menghargai alam sebagai bagian dari yang sakral memiliki kemiripan dengan masyarakat adat lainnya di Nusantara. 
Berangkat dari pemahaman bahwa budaya lokal Hibua Lamo dapat dijadikan titik pijak atau titik berangkat dalam menghadapi berbagai tantangan global termasuk berbagai konflik sosial yang terjadi dalam masyarakat, maka sudah sepantasnya jika nilai-nilai budaya Hibua Lamo tetap dipelihara kelestariannya. Sebagai local genius masyarakat Halmahera Utara Hibua Lamo dapat dijadikan global ethics bagi masyarakat lokal. Masyarakat yang bernaung di bawah Hibua Lamo hanya perlu mencari dan memperbarui format budayanya agar tidak ditelan budaya global.

\section{Hibua Lamo dalam Perspektif Habermas \\ 1. Perspektif Habermas tentang Komunikasi \\ Sebagai Unsur Penjelas Kedirian Manusia}

Memahami keberadaan alam semesta akan lebih tepat bila dimulai dengan memahami keberadaan manusia. Hal ini disebabkan karena secara kodrati manusia memiliki pengetahuan, dan seluruh konsep yang muncul adalah konsep-konsep manusia, dalam bahasa manusia, dan untuk kepentingan manusia. Bahasa dengan demikian menduduki posisi yang penting dalam dunia manusia karena melalui bahasa tersebut pengetahuannya dieksplisitkan, dan kemudian dikomunikasikan kepada orang lain. Bahasa memegang dua peranan penting sekaligus. Ia sebagai "alat" berpikir manusia, dan sekaligus sebagai "alat" untuk mengkomunikasikan pikirannya tersebut pada dirinya sendiri dan pada orang lain.

Sesuai dengan pemikiran tersebut, menurut Habermas, manusia adalah individu-individu yang bermasyarakat di atas bumi ini. Salah satu faktor penentu keberadaan manusia dan yang membedakannya dengan makhluk lain adalah komunikasi. Komunikasi dalam perspektif Habermas, sebagaimana yang distudikan oleh Hardiman, dikatakan sebagai paradigma pengada suatu masyarakat yang demokratis. Pemikiran Habermas mengenai komunikasi tersebut dapat dirunut dari perhatiannya mengenai pemisahan antara teori dan praksis. Pemisahan antara pengetahuan dan kepentingan, yang lebih dikenal dengan pemisahan antara ranah teori dan praksis, telah terjadi seiring dengan perkembangan pemikiran modern. Awal mula pemisahan itu sebenarnya telah dimulai sejak perkembangan awal filsafat di Yunani. Kontemplasi mendapatkan tempatnya sebagai upaya memahami alam semesta. Teori dipahami sebagai kontemplasi atas kosmos. Pemahaman akan yang tetap dan berubah itu melahirkan ontologi sebagai awal pemisahan pengetahuan dan kepentingan. Pemisahan itu berpuncak 
pada positivisme lewat pemikiran Auguste Comte (Hardiman, 2009a: 21-26).

Habermas mengkritisi pemisahan-pemisahan antara teori dan praksis tersebut dengan menyatakan bahwa setiap jenis pengetahuan (dan ilmu pengetahuan) lahir karena didasari oleh kepentingan tertentu. Melalui pandangannya tersebut, sesungguhnya Habermas telah berada pada titik untuk melampaui pemikiran ontologis yang berupaya menemukan teori murni dan lepas dari kepentingan praktis. Habermas, dengan kata lain, ingin kembali menegaskan tentang situasi awal Yunani kuno sebelum berkembangnya filsafat dan lahirnya ontologi, yakni bahwa ada hubungan yang sangat erat antara pengetahuan dan kepentingan empirik.

Setelah mengemukakan pandangannya yang melampaui pemikiran ontologis, Habermas kemudian mengemukakan pemikiran post-metafisikanya. Bagi Habermas, kesadaran untuk menafsirkan kembali pemahaman tentang kehidupan bersama secara politis agar sesuai dengan kebutuhan zaman merupakan upaya yang tidak bisa ditawar lagi. Habermas menyandarkan seluruh proses integrasi sosial bukan lagi kepada pra-andaian tradisional berupa pemikiran religius dan metafisika tradisional, tetapi kepada rasio (Hardiman, 2009b: 199-201). Namun demikian, pemikiran yang dimaksudkan oleh Habermas sebagai upaya untuk menyudahi pemikiran metafisika tradisional tersebut adalah sebuah paradoks karena pada saat yang sama Habermas sesungguhnya bermetafisika juga.

Terlepas dari paradoks di atas, dalam kritiknya Habermas menyatakan gagasannya tentang "Rasio Komunikatif" sebagai "Sang Paradigma". Menurut Habermas, rasio komunikatif mendapatkan tempatnya yang cocok di dalam pluralitas dan kompleksitas masyarakat modern. Rasio Komunikatif adalah tindakan berdasarkan proses musyawarah, yakni ketika dua atau lebih individu berinteraksi dan mengkoordinasikan tindakan mereka berdasarkan interpretasi dan kesepakatan terhadap situasi (Habermas, 1984:86). Manusia adalah makhluk komunikatif dan bukan saja makhluk pekerja. Kepentingan emansipasi akan mendapatkan tempatnya dalam perkembangan pengetahuan manusia dengan mengedepankan komunikasi tersebut.

Menurut Habermas, dalam konteks modern, masyarakat ini diandaikan sebagai masyarakat yang komunikatif. Masyarakat komunikatif bukanlah masyarakat yang melakukan kritik melalui 
revolusi atau kekerasan, melainkan lewat argumentasi, yaitu perbincangan atau diskursus (discourse) dan kritik. Habermas, oleh karenanya, mengusahakan dasar-dasar kerjasama sosial bagi masyarakat pluralistik modern. Perhatian Habermas adalah pada persoalan: bagaimana bisa dicapai konsensus rasional bila terjadi konflik dalam masyarakat pluralistik modern. Menurut Habermas, persoalan ini penting karena kehidupan masyarakat modern menyimpan banyak potensi konflik di berbagai bidang, baik sosial, hukum, ekonomi, maupun budaya. Adanya potensi ini memerlukan antisipasi, yang dalam hal ini adalah suatu penyelesaian dengan sebuah tindakan yang lebih komunikatif. Berawal dari gagasan inilah muncul pandangan Habermas tentang tindakan komunikatif yang berfungsi untuk mengirim dan memperbarui pengetahuan budaya dalam proses mencapai pemahaman bersama serta dalam rangka membentuk identitas (Habermas, 1984:140).

\section{Hibua Lamo dalam Teori Komunikasi Habermas}

Hibua Lamo adalah salah satu bentuk pengetahuan lokal masyarakat di Halmahera Utara. Pengetahuan lokal yang dimaksudkan di sini bisa dijelaskan dalam tiga hal. Pertama, pemahaman masyarakat lokal tentang wilayah sosio-geografis tempat hidup mereka. Berdasarkan pengertian ini, jelas bahwa hanya masyarakat lokal yang dapat mendefinisikan lingkungan hidup mereka. Setiap unsur-unsur dari luar yang hendak menegaskan keberadaan masyarakat lokal dipahami hanya sebagai tambahan saja. Kedua, tradisi-tradisi yang terus-menerus dipertahankan untuk menunjang hidup dalam habitat itu. Ketiga, pengertian masyarakat lokal tentang hak-hak mereka dalam lokalitas.

Hibua Lamo, dalam pengertian sebagai pengetahuan lokal, hadir sebagai ekspresi masyarakat demi keberlangsungan masyarakat ketika dihadapkan pada situasi konflik yang menuntut solusi. Hibua Lamo lahir sebagai hubungan antar kelompok yang mendefinisikan situasi mereka sendiri. Hibua Lamo, dengan demikian, bukanlah hubungan yang diusulkan oleh pihak-pihak di luar masyarakat lokal tetapi merupakan hubungan yang dilahirkan oleh masyarakat itu sendiri untuk menunjang hidup dalam lingkungan saat itu.

Hibua Lamo dalam kenyataannya merupakan integrasi masyarakat primitif yang dilakukan atas dasar konsensus normatif dasar. Berdasarkan pengertian itu, dapat dikatakan bahwa konsensus tentang Hibua Lamo hadir bukan sebagai hasil dari 
argumentasi-argumentasi yang dilakukan di dalam ruang publik lewat etika diskursus yang demokratis. Konsensus tentang Hibua Lamo tersebut hadir dalam penekanan makna dalam masyarakat tradisional yang masih sangat paternalistik, yakni ketika pemimpin yang menentukan bagaimana bentuk suatu masyarakat.

Membahas eksistensi Hibua Lamo dalam perspektif Habermas sebenarnya bukanlah upaya yang mudah. Kesulitannya adalah pada kesenjangan antara konteks ketika Hibua Lamo hadir, dan konteks ketika teori komunikatif Habermas muncul. Hibua Lamo, di satu sisi, hadir sebagai bentuk integrasi sosial dalam masyarakat primitif yang tradisional dan paternalistik yang menekankan peranan penting dari makna dalam komunikasi. Teori komunikasi Habermas, di sisi yang lain, lahir sebagai bentuk kritik terhadap kehidupan masyarakat modern yang maju dan telah mengenal pembagian-pembagian fungsi yang rumit. Teori komunikasi Habermas lahir sebagai bentuk kritik terhadap aneksasi sistem pasar dan negara ke dalam ruang hidup masyarakat sehingga seluruh aktivitas masyarakat hanya diarahkan pada kerja. Manusia sebagai makhluk pekerja, itulah yang dikritik oleh Habermas dengan mengedepankan manusia sebagai makhluk komunikatif juga (Habermas, 1984:95).

Kesenjangan konteks adalah satu hal yang memang selalu ada dalam kenyataan. Namun demikian, perkembangan zaman tetap membutuhkan transformasi hubungan-hubungan sosial. Transformasi itu dibutuhkan agar tidak ketinggalan zaman dan tetap dapat digunakan sebagai bentuk integrasi sosial. Halmahera Utara pun bisa dikatakan mengalami situasi yang dikritik oleh Habermas, yakni ketika ruang hidup masyarakat dianeksasi oleh sistem pasar dan negara. Hal itu sangat nyata ketika seluruh institusi sosial budaya masyarakat tradisional digantikan oleh sistem negara dan pasar yang mengedepankan rasionya sendiri. Menurut Habermas, rasio yang mendasari sistem pasar dan negara adalah rasio instrumental, sementara rasio yang mendasari ruang hidup masyarakat adalah rasio komunikatif. Melalui penggunaan rasio komunikatif, diharapkan ada semacam transformasi dalam integrasi sosial. Transformasi itu hanya dapat terjadi ketika komunikasi yang dilakukan dalam ruang publik hadir tanpa penekanan makna. Seluruh klaim-klaim kebenaran dipertanyakan kembali sehingga yang diutamakan hanyalah argumentasi-argumentasi. Rasio komunikatif berfungsi untuk memperbarui pengetahuan budaya dalam proses pencapaian pemahaman bersama lewat integritas dan 
solidaritas yang mengarah pada pembentukan identitas masyarakat (Habermas, 1984:140).

Hibua Lamo sebagai hubungan sosial masyarakat Halmahera Utara, dengan demikian, mendapatkan tempatnya dalam pemikiran Habermas, khususnya mengenai rasio komunikatif. Pandangan dasarnya sama, yakni bahwa ada hal-hal yang tidak bisa dianeksasi oleh sistem pasar dan negara dan merupakan kekuatan tersendiri bagi masyarakat. Hibua Lamo adalah bagian dari hal tersebut karena Hibua Lamo telah melewati ujian terberat, yakni tragedi kemanusiaan di Halmahera Utara. Ujian itu sekaligus mentransformasi Hibua Lamo yang menghargai pluralitas.

Ada hal yang memang berubah sesuai dengan perkembangan zaman tetapi ada hal yang tidak berubah dari ikatan budaya Hibua Lamo itu, yaitu hal yang mendasarinya. Walaupun sebenarnya dalam pengertian Habermas komunikasi dipahami dalam pengertian tindak wicara dengan mengedepankan argumentasi, namun rasio komunikatif tetap mendapatkan tempatnya dalam budaya Hibua Lamo.

Hibua Lamo adalah ikatan budaya sekaligus lambang pemersatu yang tertanam dalam dada setiap masyarakat Halmahera Utara. Konsensus ini ditetapkan sejak nenek moyang oleh para pemimpin kelompok-kelompok masyarakat (Soa) yang telah lebih dulu melakukan pembangunan Hibua Lamo ini. Jika mengaku sebagai masyarakat Hibua Lamo maka nilai-nilai budaya ini akan ditaati sehingga mampu mempersatukan orang-orang yang ada di dalamnya dan memunculkan keteraturan hidup serta persatuan bagi penghuni "Rumah Besar" Hibua Lamo di masa yang akan datang.

\section{E. Penutup}

Tulisan ini sebenarnya dibuat dengan sedikit pesimisme. Pesimisme itu lahir karena adanya kesenjangan konteks yang sangat besar antara situasi ketika budaya Hibua Lamo lahir dengan situasi yang menjadi sasaran kritik dari Habermas. Hibua Lamo lahir dalam konteks masyarakat tradisional yang masih primitif dan sangat paternalistik, sementara kritik Habermas lahir dalam konteks masyarakat modern yang mengedepankan rasio instrumental lewat kerja. Walaupun demikian, ada satu hal yang dapat ditarik dari pemikiran Habermas, dalam upaya merasionalisasikan budaya Hibua Lamo yang lahir sebagai bagian dari ekspresi pengetahuan lokal masyarakat Halmahera Utara. Hal itu adalah rasio komunikasi yang mendasari Hibua Lamo sebagai bentuk integrasi sosial 
masyarakat di era modern ini. Rasio komunikasi semakin mendapatkan tempatnya ketika hubungan kekerabatan dalam budaya Hibua Lamo diuji oleh tragedi kemanusiaan di Halmahera Utara yang meluluhlantakkan seluruh sendi-sendi kehidupan masyarakat, termasuk ikatan-ikatan yang telah terbangun selama ratusan tahun itu.

Berdasarkan pada rasio komunikatif dalam perspektif Habermas, Hibua Lamo mendapatkan spiritnya untuk menghadapi kehidupannya yang baru. Transformasi budaya Hibua Lamo ditandai dengan adanya keterbukaan berargumentasi di ruang publik dengan tiada lagi penekanan makna, namun demi pencapaian konsensus. Konsensus bersama kelompok-kelompok yang mengaku sebagai bagian dari Hibua Lamo adalah bentuk dari penyelesaian konflik.

Hibua Lamo sebelum konflik kemanusiaan hanyalah ideologi yang dibungkus oleh mitos dan terus diingatkan dari generasi ke generasi lewat perayaan ritus-ritus. Setelah konflik, Hibua Lamo merupakan bentuk integrasi sosial yang tidak lagi dirayakan lewat ritus-ritus tetapi ditempatkan dalam diskursusdiskursus publik yang ilmiah. Argumentasi-argumentasi dikemukakan sehingga lahirlah bentuk Hibua Lamo yang baru, yang dimaknai sebagai bukan saja sebagai "rumah besar" di era para leluhur, tetapi lebih dari itu, yakni sebagai dasar kekeluargaan dan pemersatu serta pemicu untuk memajukan kehidupan bersama masyarakat yang bernaung di bawahnya.

\section{Daftar Pustaka}

Ajawaila, J,W, 2009, "Budaya Hibua Lamo dalam Tantangan Masa Depan", dalam Hein dan Hibua Lamo, Tobelo Pos dan Pemda Kabupaten Halmahera Utara, Tobelo.

Habermas, J, 1984, Theory of Communicative Action, translated by Thomas McCarthy, Beacon Press, Boston.

Hardiman, F, B., 2009a, "Demokrasi Deliberatif: Menimbang 'Negara Hukum' dan 'Ruang Publik'” dalam Teori Diskursus Jürgen Habermas, Kanisius, Yogyakarta.

, 2009b, Kritik Ideologi: Menyingkap Pertautan Pengetahuan dan Kepentingan bersama Jürgen

Habermas, (ed. Ke-3), Kanisius, Yogyakarta.

Kuat, Wilson, 2009, "Nilai-Nilai Adat Hibua Lamo dan 
Implikasinya bagi Pembangunan Halmahera Utara", dalam Hein dan Hibua Lamo, Tobelo Pos dan Pemda Kabupaten Halmahera Utara, Tobelo.

Kuntowijoyo, 2003, Metodologi Sejarah, edisi kedua, Tiara Wacana, Yogyakarta.

Mesdila, Elizabeth, Helena, 2005, Perempuan dalam Hibua Lamo, Program Pasca Sarjana Magister UKSW, Salatiga.

Mojau, Julianus, 2001, Religiositas Masyarakat Halmahera Tradisional dan Pengaruhnya Terhadap Kehidupan Mereka Sehari-hari, Oase Intim, Makasar.

Namotemo, Hein, 2009, "Struktur dan Rumah Adat", dalam Hein dan Hibua Lamo, Tobelo Pos dan Pemda Kabupaten Halmahera Utara, Tobelo.

Vanisna, Jan, 1969, Oral Tradition: A Study Historical

Methodology, Routledge \& Kegan Paul, London.

Wachterhauser, Brice R., 1986, "History and Language in Understanding", dalam Hermeneutics and Modern Philosophy, edited by. Brice R. Wachterhauser, State University of New York, New York.

\section{Sumber lain:}

Http://www.halutkab.go.id, Profil Kabupaten Halmahera Utara 2009, diakses 20 Januari 2010.

Labada, Clion K., 2007, Asal-usul dan Eksistensi Hibualamo, http://www.halmaherautara.com, diakses 20 Januari 2010.

Maspaitella, Tomix, Elifas, 2008, Solohua Kasale Patai: Mitos Gunung Suci pada Suku Wemale di Pulau Seram -Maluku, http://kutikata.blogspot.com/2008/01/ solohua-kasale-patai.html, diakses 20 Januari 2010. 